\title{
Persepsi Ibu Hamil Tentang Budaya Dan Mitos Kehamilan di Wilayah Kerja Puskesmas Padangan Kabupaten Bojonegoro
}

\author{
Husnul Muthoharoh ${ }^{1}$ \\ ${ }^{1}$ Dosen Program Studi D III Kebidanan Universitas Islam Lamongan \\ Email: ques.muth@gmail.com
}

\begin{abstract}
ABSTRAK
Proses kehamilan tidak bisa lepas dari mitos yang berkembang di masyarakat terutama di pulau Jawa yang masih kental dengan budaya Jawa. Padahal, mitos yang terjadi di masyarakat tidak sepenuhnya sejalan dengan ilmu pengetahuan yang telah berkembang, bahkan masih banyak mitos tentang kehamilan yang membahayakan keselamatan ibu dan janin.

Penelitian ini menggunakan metode penelitian deskriptif yang berfungsi untuk mendeskripsikan atau memberi gambaran terhadap obyek yang diteliti melalui data sampel atau populasi sebagaimana adanya, tanpa melakukan analisis dan membuat kesimpulan yang berlaku untuk umum. Metode pendekatan yang digunakan adalah pendekatan cross sectional. Populasi penelitian ini adalah ibu hamil yang memeriksakan dirinya di Puskesmas Padangan Kabupaten Bojonegoro. Pengambilan sampel menggunakan teknik total sampling, sejumlah 47 ibu hamil..

Dari hasil penelitian ini menunjukkan bahwa mayoritas ibu hamil mendapatkan dukungan personal dari suami yakni sebesar 39\%. Mayoritas ibu hamil lebih senang jika berdiskusi terkait masalah kehamilannya dengan suami yakni sebesar $74,5 \%$. Sumber nasihat paling banyak dipercaya oleh ibu hamil adalah dari orang tua yakni sebesar 95,7\%. Dari aspek budaya, ibu hamil di wilayah kerja pukesmas Padangan Bojonegoro masih banyak yang mempercayai mitos mulai dari pantang makan sampai pantang berperilaku. Persepsi ibu hamil tentang mitos juga masih cukup tinggi yakni mitos positif sebesar 59,6\%.

Kesimpulan dari penelitian ini adalah masih banyak ibu hamil yang percaya dengan budaya dan mitos terkait dengan kehamilan.
\end{abstract}

Kata Kunci: Persepsi, Ibu hamil, Budaya, Mitos. 
PENDAHULUAN

Masyarakat Jawa masih memiliki nilai-nilai budaya yang banyak diterapkan di berbagai wilayah pulau Jawa. Salah satu daerah yang masih kental akan budaya Jawanya adalah Kabupaten Bojonegoro. Van Gennep (1960) dalam Winson (2006) menggambarkan status sosial seorang wanita pada saat hamil berada pada status marginality di mana dia mulai berperilaku berbeda dari biasanya misalnya dengan memperhatikan pola makan, aktifitas, dan lain-lain. Masyarakat di berbagai budaya memberi perhatian pada fase krisis ini. Pada masa kehamilan ada banyak ritual yang harus dilakukan yang menandakan bahwa masyarakat di budaya mana pun menganggap kehamilan sebagai peristiwa yang luar biasa, bukan hanya dalam kehidupan wanita hamil itu sendiri tetapi juga suami dan keluarganya.

Kesehatan selama kehamilan dapat dipengaruhi oleh beberapa faktor. Diantaranya adalah mitosmitos seputar kehamilan (Peuersen, 1988). Mitos kehamilan masih banyak ditemukan di Indonesia sesuai dengan budaya dan adat istiadat daerahnya masing-masing. Mitos yang berkembang di Sumatera pasti berbeda dengan mitos yang berkembang di pulau Jawa. Di Kabupaten Bojonegoro pun masih banyak berkembang budaya dan mitos bagi ibu hamil.

Mitos yang terjadi di masyarakat tidak sepenuhnya sejalan dengan ilmu pengetahuan yang telah berkembang, bahkan masih banyak mitos tentang kehamilan yang membahayakan keselamatan ibu dan janin. Mitos adalah pendapat atau anggapan dalam sebuah kebudayaan yang dianggap mempunyai kebenaran yang isinya tentang anjuran maupun larangan mengenai kehamilan yang pernah berlaku pada suatu masa dahulu hingga sekarang tentunya banyak beredar di masingmasing daerah dan belum tentu kebenarannya (Nirwana, A.B, 2011). Persepsi terhadap mitos kehamilan baik masalah kematian maupun kesakitan pada ibu sesungguhnya tidak terlepas dari faktor-faktor sosial budaya dan lingkungan dalam masyarakat dimana mereka berada. Disadari atau tidak, faktor-faktor kepercayaan dan pengetahuan budaya seperti konsepsi-konsepsi mengenai berbagai pantangan, hubungan sebab-akibat antara makanan dan kondisi sehat-sakit, kebiasaan dan ketidaktahuan, seringkali membawa dampak baik positif maupun negatif terhadap kesehatan reproduksi ibu dan kesehatan anak. Hal ini terlihat bahwa setiap daerah mempunyai pola makan tertentu, termasuk pola makan ibu hamil yang disertai dengan kepercayaan akan pantangan, tabu, dan anjuran terhadap beberapa makanan tertentu (Nirwana, A.B, 2011). Budaya pantang pada ibu hamil sebenarnya justru merugikan kesehatan ibu hamil dan janin yang dikandungnya. Misalnya ibu hamil dilarang makan telur dan daging, padahal telur dan daging justru sangat diperlukan untuk pemenuhan kebutuhan gizi ibu hamil dan janin. Berbagai pantangan tersebut akhirnya menyebabkan ibu hamil kekurangan gizi seperti anemia dan kurang energi kronis (KEK). Dampaknya, ibu mengalami pendarahan pada saat persalinan dan bayi yang dilahirkan memiliki berat badan rendah (BBLR) yaitu bayi lahir dengan berat kurang dari $2.5 \mathrm{~kg}$ 
(Manuaba, 2010). Berdasarkan permasalahan tersebut peneliti tertarik untuk melakukan penelitian dengan judul "Persepsi Ibu Hamil Tentang Budaya Dan Mitos Kehamilan di Wilayah Kerja Puskesmas Padangan Kabupaten Bojonegoro"

\section{METODE PENELITIAN}

Penelitian ini menggunakan metode penelitian deskriptif yang berfungsi untuk mendeskripsikan atau memberi gambaran terhadap obyek yang diteliti melalui data sampel atau populasi sebagaimana adanya, tanpa melakukan analisis dan membuat kesimpulan yang berlaku untuk umum. Metode pendekatan yang digunakan adalah pendekatan cross sectional. Populasi penelitian ini adalah ibu hamil yang memeriksakan dirinya di Puskesmas Padangan Kabupaten Bojonegoro. Pengambilan sampel menggunakan teknik total sampling, sejumlah 47 ibu hamil. Instrumen menggunakan kuesioner. Analisa statistik deskriptif dengan pengukuran distribusi frekuensi dan modus.

Penelitian ini dilakukan pada bulan Desember 2016 di Puskesmas Padangan Kabupaten Bojonegoro.

\section{HASIL PENELITIAN}

1. Karakteristik Responden

Berdasarkan Umur

Tabel 1. Distribusi Umur Responden

\begin{tabular}{llll}
\hline No. & $\begin{array}{l}\text { Umur } \\
\text { (tahun) }\end{array}$ & Frekuensi & \% \\
\hline 1. & $17-25$ & 14 & 29,8 \\
2. & $26-32$ & 20 & 42,5 \\
3. & $33-40$ & 13 & 27,7 \\
\multicolumn{2}{l}{ Total } & 47 & 100 \\
\hline
\end{tabular}

Berdasarkan tabel 1 di atas diketahui bahwa umur responden terbanyak yaitu 26-32 tahun berjumlah 20 orang dengan prosentase $42,5 \%$. Responden yang berumur 17-25 tahun berjumlah 14 orang dengan prosentase $29,8 \%$. Responden berumur 33-40 tahun berjumlah 13 orang dengan prosentase $27,7 \%$.

2. Karakteristik Responden

Berdasarkan Tingkat Pendidikan

Tabel 2. Distribusi Pendidikan Responden

\begin{tabular}{|c|c|c|c|}
\hline No. & Pendidikan & Frekuensi & $\%$ \\
\hline 1. & SMP & 14 & 29,8 \\
\hline 2. & SMA & 26 & 55,3 \\
\hline 3. & PT & 7 & 14,9 \\
\hline & Total & 47 & 100 \\
\hline
\end{tabular}
berpendidikan SMA sejumlah 26 orang dengan prosentase $55,3 \%$ dan berpendidikan paling sedikit yaitu Perguruan Tinggi (PT) sejumlah 7 orang dengan prosentase $14,9 \%$.

3. Karakteristik Responden Berdasarkan Pekerjaan

Tabel 3 Distribusi Pekerjaan Responden

\begin{tabular}{llcc}
\hline No. & Pekerjaan & Frekuensi & \% \\
\hline 1. & IRT & 25 & 53,2 \\
2. & Swasta & 16 & 34 \\
3. & PNS & 6 & 12,8 \\
\hline & Total & 47 & 100 \\
\hline
\end{tabular}

Dari tabel 3 di atas, pekerjaan terbanyak yakni IRT sejumlah 25 orang dengan prosentase $53,2 \%$.

4. Aspek Sosial Ibu Hamil di Puskesmas Padangan,

Kabupaten Bojonegoro

Tabel 4 Distribusi Aspek Sosial Ibu Hamil di Puskesmas Padangan, Kabupaten Bojonegoro 


\begin{tabular}{lcc}
\hline $\begin{array}{l}\text { Aspek } \\
\text { Sosial }\end{array}$ & $\mathbf{n = 4 7}$ & $\begin{array}{l}\text { Prosentase } \\
(\boldsymbol{\%})\end{array}$ \\
\hline \multicolumn{2}{l}{ Dukungan } & Personal \\
Suami & 39 & 83 \\
Orang Tua & 5 & 10,6 \\
Bidan & 3 & 6,4 \\
Diskusi & Terkait & Keluhan \\
Kehamilan & & \\
Suami & 35 & 74,5 \\
Orang tua & 2 & 4,3 \\
Bidan & 10 & 21,2 \\
Sumber Nasihat & \\
Orang tua & 45 & 95,7 \\
Mertua & 2 & 4,3 \\
\hline
\end{tabular}

Tabel 4 di atas adalah aspek sosial yang meliputi dukungan personal ibu hamil, diskusi dengan personal terkait keluhan kehamilan dan sumber nasihat/informasi terkait kehamilan. Hasil penelitian aspek sosial ibu hamil pada variable dukungan personal mayoritas sejumlah 39 responden dengan prosentase $83 \%$ mendapatkan dukungan personal dari suami. Sejumlah 5 orang dengan prosentase $10,6 \%$ mendapatkan dukungan personal dari orang tua dan 3 responden dengan prosentase $6,4 \%$ mendapatkan dukungan personal dari bidan.
Pada variabel diskusi dengan personal terkait keluhan kehamilan, hasil penelitian menunjukkan bahwa mayoritas ibu hamil mengkomunikasikan keluhannya kepada suami sebanyak 35 responden $(74,5 \%)$. 10 responden $(21,2 \%)$ mengkomunikasikan keluhan kehamilan kepada bidan. Dan 2 responden lainnya $(4,3 \%)$ mengkomunikasikan keluhan kehamilan kepada orangtua.

Hasil penelitian variabel sumber nasihat informasi terkait kehamilan menunjukkan bahwa sumber nasihat atau anjuran ibu hamil sebanyak 45 responden $(95,7 \%)$ percaya kepada nasihat yang diberikan orangtua, sedangkan 2 lainnya (4,3\%) percaya pada nasihat mertua.

5. Aspek Budaya Ibu Hamil di Puskesmas Padangan, Kabupaten Bojonegoro

Tabel 5 Distribusi Aspek Budaya Ibu Hamil di Puskesmas Padangan, Kabupaten Bojonegoro

Tabel 5. Aspek Budaya Ibu Hamil di Puskesmas Padangan Kabupaten Bojonegoro

\begin{tabular}{lcc}
\hline \multicolumn{1}{c}{ Aspek Budaya } & $\mathrm{n}=47$ & $\begin{array}{c}\text { Prosentase } \\
(\%)\end{array}$ \\
\hline Pantangan Makanan & 9 & 19,1 \\
Makan Tape & 7 & 15 \\
Makan Durian & 10 & 21,3 \\
Makan Nanas & 9 & 19,1 \\
Makanan amis & 12 & 25,5 \\
Tidak Ada Pantangan Makanan & & \\
\hline Pantangan Perilaku & 10 & 21,3 \\
Tidak Boleh Melilitkan Handuk di Leher & 26 & 55,3 \\
Ibu Hamil Tidak Boleh Mandi Diatas Jam 5 & & 17,0 \\
Sore & 8 & 6,4 \\
Tidak Boleh Keluar Rumah di Malam Hari & 3 & 23,4 \\
Tidak Ada Pantangan Berperilaku & & \\
\hline Nasihat Berperilaku & 11 & \\
Sering Jalan Pagi & &
\end{tabular}


Membawa pisau saat keluar rumah

Wanita hamil yang dianjurkan minum minyak kelapa sebelum kelahiran dan banyak minum air kelapa tidak menimbulkan manfaat apapun dan sangat tidak ada kaitannya dengan proses kelahiran. Semua zat makanan akan dipecah dalam usus halus dan dijadikan glukosa, asam lemak, asam amino dan lain-lain agar mudah di absorbsi oleh usus.

Tabel 5 adalah aspek budaya yang terdiri dari pantangan makan, pantangan perilaku, dan nasihat perilaku. Aspek budaya yang diteliti adalah variable pantang makan, budaya pantangan berperilaku, dan nasihat berperilaku dari orang tua.

Hasil penelitian pada aspek budaya variable pantang makan menunjukkan mayoritas ibu hamil memiliki budaya pantang makan pada beberapa jenis buah-buahan seperti nanas sejumlah 10 responden $(21,3 \%)$. Sejumlah 9 responden $(19,1 \%)$ pantang makan tape, sejumlah 9 responden $(19,1 \%)$ pantang makan ikan, sejumlah 7 responden (15\%) pantang makan durian, dan sejumlah 12 responden $(25,5 \%)$ tidak memiliki pantangan terhadap makanan apapun.

Hasil penelitian pada pantangan perilaku menunjukkan ibu hamil yang pantang terhadap beberapa perilaku tertentu diantaranya sebanyak 26 responden $(55,3 \%)$ tidak boleh mandi di atas jam 5 sore. Sebanyak 10 responden $(21,3 \%)$ memiliki pantangan tidak boleh melilitkan handuk di leher, sebanyak 8 responden $(17,0 \%)$ tidak boleh keluar pada malam hari, dan 3 responden $(6,4 \%)$ tidak memiliki pantangan dalam berperilaku.

Variabel nasihat berperilaku dari orang tua terdahulu yakni mayoritas ibu hamil mendapat nasihat untuk sering berjalan pagi sebanyak 11 responden $(23,4 \%), \quad$ sebanyak 21 responden (44,7\%) mendapatkan nasihat untuk minum air kelapa selama masa kehamilan, sebanyak 7 responden (14,9\%) mendapatkan nasehat untuk memakai peniti di baju selama hamil, sebanyak 1 responden $(2,1 \%)$ mendapatkan nasehat untuk minum minyak sayur saat hamil tua dan membawa pisau saat keluar rumah, dan 6 responden $(12,8 \%)$ tidak mendapatkan nasehat untuk pantang melakukan perilaku apapun.

6. Persepsi Ibu Hamil Tentang Mitos Kehamilan di Wilayah 
Kerja Puskesmas Padangan Bojonegoro

\begin{tabular}{lcc}
\hline Variabel & $\mathrm{N}$ & $\%$ \\
\hline Positif & 28 & 59,6 \\
Negatif & 19 & 40,4 \\
\hline \multicolumn{1}{c}{ Total } & 47 & 100 \\
\hline
\end{tabular}

Berdasarkan tabel 6 menunjukkan ibu hamil yang mempunyai mitos positif sebanyak 28 responden $(59,6 \%)$ dan ibu hamil yang memiliki mitos negatif adalah sebanyak 19 responden $(40,4 \%)$.

\section{PEMBAHASAN}

Karakteristik responden berdasarkan umur menunjukkan bahwa mayoritas responden berumur 26-32 tahun. Usia bisa dikaitkan dengan pengalaman pribadi, apa yang pernah dan sedang dialami seseorang akan ikut membentuk dan mempengaruhi rangsangan sosial seseorang. Pada rentang usia $17-25$ tahun, merupakan usia yang muda dan mayoritas baru pertama kali mengalami kehamilan (primi gravida) sehingga pengalaman akan kehamilan belum banyak didapat. Hal tersebut menyebabkan banyak responden yang masih menuruti perkataan orang tua dan orang tua terdahulu untuk percaya mitos karena takut terjadi hal yang tidak diinginkan pada kehamilannya jika tidak mempercayainya. Usia responden merupakan usia kategori dewasa. Usia tersebut responden sudah mempunyai pengalamanpengalaman seputar kehamilan baik pengalaman pribadi maupun pengalaman dari lingkungan sekitar seperti keluarga atau teman (Notoatmodjo, 2012).

Karakteristik responden berdasarkan variabel pendidikan mayoritas responden berpendidikan SMA. Semakin tinggi tingkat pendidikan seseorang maka semakin tinggi pula tingkat pengetahuannya (Notoatmodjo, 2003). Pendidikan erat kaitannya dengan tingkat pengetahuan. Pendidikan diartikan sebagai sebuah upaya dalam membangun kepribadian dan kemampuan seseorang. Konsep pendidikan didefinisikan sebagai upaya yang dilakukan oleh seseorang atau kelompok untuk perubahan menjadi dewasa serta memperoleh taraf hidup yang lebih baik (Hasbullah, 2012).

Menurut Budiman \& Riyanto (2013) pendidikan dapat diperoleh secara formal dan informal. Semakin tinggi tingkat pendidikan maka diharapkan individu memiliki pengetahuan yang luas dan pemahaman baik. Pendidikan yang tinggi sejalan dengan kemudahan dalam akses informasi.

Pendidikan dapat membentuk pengetahuan seseorang dan pengetahuan dapat membentuk sikap. Responden yang berpendidikan rendah ditempat penelitian sangat patuh dengan mitos- mitos yang berkembang seputar kehamilan baik itu mitos yang sesuai dengan ilmu pengetahuan maupun mitos yang tidak sesuai dengan ilmu pengetahuan. Mereka cenderung takut jika terjadi sesuatu dengan kehamilannya jika mereka tidak mengikuti mitos tersebut. Sedangkan responden yang berpendidikan lebih tinggi 
menelaah dulu tentang mitos yang berkembang, jika sangat tidak sesuai dengan informasi dari tenaga kesehatan mereka tidak akan lakukan atau turuti. Responden yang berpendidikan lebih tinggi ditempat penelitian lebih mempercayai dokter dari pada mitos yang berkembang. Namun jika mitos tersebut tidak terkait dengan masalah kesehatan biasanya mereka juga mengikutinya.

Walaupun mayoritas responden berpendidikan SMA, namun kepercayaan terhadap mitos bukan hanya dipengaruhi oleh faktor pendidikan, tetapi juga dipengaruhi oleh faktor lain seperti usia, usia kehamilan dan pekerjaan. Pengetahuan sangat berhubungan dengan pendidikan dimana seseorang dengan pendidikan tinggi maka tingkat pengetahuannya pun akan semakin luas. Namun perlu diketahui bahwa seseorang dengan pendidikan rendah tidak berarti pengetahuannya juga rendah. Taraf pengetahuan seseorang bukan hanya diperoleh dari pendidikan formal, akan tetapi juga dapat diperoleh dari pendidikan non formal.

Karakteristik responden berdasarkan pekerjaan, mayoritas responden bekerja sebagai ibu rumah tangga. Ibu rumah tangga memiliki banyak waktu luang dirumah sehingga waktu luang tersebut biasanya dipakai untuk mengobrol bersama tetangga, saudara, mertua dan orangtua sehingga informasi yang didapat seputar mitos tentang kehamilan semakin kuat. Dibandingkan dengan ibu pekerja yang hanya memiliki sedikit waktu untuk bertukar informasi seputar kehamilan.

Variabel status pekerjaan menunjukkan bahwa mayoritas responden bekerja sebagai IRT. Status pekerjaan kurang bisa menggambarkan persepsi ibu dalam menyikapi mitos kehamilan. Hal tersebut dikarenakan banyak ibu yang memiliki pendidikan tinggi akan tetapi lebih memilih menjadi ibu rumah tangga. Dengan kata lain, status pekerjaan tidak bisa menggambarkan tingkat pengetahuan ibu hamil.

Penelitian Widayanti (2014) menjelaskan bahwa pekerjaan membuat seseorang mempunyai banyak teman dilingkungan kerjanya. Pada dasarnya, individu lebih bersikap sesuai dengan sikap orang yang dianggapnya berpengaruh. Kecenderungan tersebut didukung oleh kesediaan individu untuk menjauhi masalah dengan orang yang dianggap berpengaruh tersebut. Ibu yang tidak bekerja cenderung tidak terlalu disibukkan dengan tugas ganda yaitu bekerja dan pekerjaan rumah tangga. Ibu yang tidak bekerja memiliki banyak waktu untuk bersosialisasi dengan tetangganya, hal tersebut menyebabkan budaya tentang mitos seputar kehamilan sering menjadi pembicaraan antara mereka tanpa didasari oleh pengetahuan medis yang benar karena biasanya mereka hanya 
mengaitkan kejadian yang terjadi dengan kebiasaan yang dilakukan.

Aspek sosial yang diteliti adalah dukungan personal, diskusi terkait keluhan kehamilan dan sumber nasihat. Pada variabel dukungan personal mayoritas mendapat dukungan dari suami. Dukungan suami sangat diharapkan oleh seorang ibu hamil, misalkan suami menunjukkan perhatiannya selama hamil, menuruti segala apa yang diinginkan oleh istri, dan tidak ingin menyakiti istri. Seiring dengan penelitian Fauziah yang mengatakan bahwa interaksi sosial wanita hamil sangat diperlukan baik berupa dukungan psikologis, kasih sayang, perhatian, empati dan pengorbanan terutama dari pihak suami dan keluarga. Menurut sisi psikologis, ibu hamil akan mengalami perubahan hormone yang menyebabkan perubahan kondisi fisik dan emosional. Hal tersebut yang membuat ibu hamil sangat memerlukan dukungan dan perhatian dari orang-orang terdekat (Fauziah, 2008).

Karakteristik responden pada variabel diskusi terkait keluhan kehamilan, mayoritas ibu hamil mengeluh kepada suami. Sebenarnya bidan, dokter atau petugas kesehatan lain merupakan sumber informasi terbaik dibandingkan orangtua yang hanya tau lewat pengalaman saja. Penelitian oleh Fauziah (2008) menyatakan bahwa pantangan dan anjuran yang diperuntukkan bagi ibu hamil banyak disampaikan oleh orang tua, mertua, dan keluarga. Bahkan banyak dari ibu hamil percaya jika tidak mengikuti anjuran orang tua terdahulu maka akan membahayakan kehamilannya.

Kebudayaan yang ada di suatu daerah tertentu berpengaruh pada persepsi seseorang terhadap kehamilan. Pada dasarnya masyarakat mencemaskan masa kehamilan dan persalinan. Dalam budaya masyarakat kita, seseorang yang hamil dan yang akan melahirkan dilindungi secara kepercayaan, moral dan adat yang bertujuan untuk menjaga keselamatan ibu dan bayi.

Variabel budaya makan menunjukkan bahwa mayoritas ibu hamil memiliki pantangan makanan terhadap nanas. Hal tersebut karena makan nanas dipercaya dapat menyebabkan Rahim akan terasa panas dan dapat menyebabkan keguguran. Dalam teori, sebenarnya nanas banyak mengandung vitamin dan mineral yang bermanfaat untuk kesehatan ibu hamil. Buah Nanas mengandung bromealin yakni enzim yang dapat membantu melemahkan serviks, oleh karena itu tidak boleh dikonsumsi dalam jumlah banyak. Kesalahan pemahaman tentang nanas di masyarakat yakni nanas mengandung enzim bromelain yang dipercaya bisa menyebabkan keguguran. Padahal nanas memiliki manfaat bagi ibu hamil, diantaranya adalah sebagai sumber vitamin $\mathrm{C}$ 
dan memenuhi kebutuhan kolagen bagi ibu hamil di mana kolagen tersebut bisa menyokong pertumbuhan kulit, tulang, dan bagian tubuh lainnya.

Beberapa ibu hamil percaya bahwa mereka tidak boleh makan makanan yang amis karena mereka beranggapan bahwa makanan amis menyebabkan bayi dan air ketuban menjadi berbau amis dan menyebabkan perdarahan setelah proses persalinan. Padahal ikan mempunyai kandungan lemak yang baik dan bisa digunakan sebagai penopang tumbuh kembang janin. Sebuah penelitian yang berasal dari Barcelona Institute for Global Health menyebutkan bahwa konsumsi ikan laut selama kehamilan dapat meningkatkan kemampuan otak janin terutama konsentrasi saat mereka belajar di sekolah.

Hasil wawancara dengan ibu hamil didapatkan bahwa mereka yang berpantang makan terhadap tape dan durian beranggapan bahwa makanan tersebut dapat mengganggu kondisi kehamilan dan hal ini sejalan dengan teori Tino (2009) yang mengatakan bahwa dalam tape dan durian terdapat kandungan alkohol yang menyebabkan tubuh menjadi panas sehingga dapat mengancam kondisi janin dan bisa menyebabkan keguguran.

Karakteristik responden
pada variabel pantangan
berperilaku mayoritas ibu hamil
memiliki pantangan untuk tidak
melilitkan handuk di leher. Ibu

hamil yang memiliki keyakinan dilarang melilitkan handuk di leher percayajika melakukan hal tersebut maka ketika bayi lahir akan mengalami lilitan tali pusat, padahal dalam teori Tino (2009) menyebutkan bahwa lilitan tali pusat terjadi karena aktivitas yang berlebihan sehingga menyebabkan hiperaktivitas gerakan bayi.

Suatu kebiasaan atau adat yang ada dalam masyarakat merujuk ke pola kepercayaan dan perilaku yang telah menjadi bagian dari budaya yang sudah lama dipercaya secara turun temurun yang secara sosial diwariskan dari generasi ke generasi berikutnya (Supardan, 2008).

Variabel
berperilaku dari $\begin{array}{r}\text { nasihat } \\ \text { orangtua }\end{array}$
dahulu mayoritas ibu hamil
dinasihati untuk sering jalan
pagi selama hamil. Nasihat
untuk sering jalan pagi selama
kehamilan adalah mitos yang
bermanfaat
menguntungkan bagi ibu hamil. Karena jalan pagi adalah salah satu alternatif olahraga ibu hamil yang dianjurkan. Manfaat jalan pagi bagi ibu hamil adalah dapat membantu ibu menghilangkan ketidaknyamanan selama kehamilan seperti morning sickness atau mual muntah yang hanya dirasakan pada pagi hari.

Wanita hamil yang dianjurkan minum minyak kelapa sebelum kelahiran dan banyak minum air kelapa tidak menimbulkan manfaat apapun 
dan sangat tidak ada kaitannya dengan proses kelahiran. Semua zat makanan akan dipecah dalam usus halus dan dijadikan glukosa, asam lemak, asam amino dan lain-lain agar mudah di absorbsi oleh usus.

\section{SIMPULAN DAN SARAN}

\section{Simpulan}

Sebagian besar responden berada pada rentang usia 26-32 tahun sebanyak 20 responden atau sebesar 42,5\%. Mayoritas berpendidikan SMA sebanyak 26 responden (55,3\%). Mayoritas bekerja sebagai IRT sebanyak 25 responden $(23,5 \%)$.

Dari segi budaya yang didapatkan dari ibu hamil di Puskesmas Padangan Kabupaten Bojonegoro masih percaya terhadap mitos dan memiliki kepercayaan tentang pantang terhadap beberapa jenis makanan, pantangan dalam berperilaku dan serta mengikuti anjuran atau nasehat pantangan dari orang tua terdahulu.

\section{Saran}

Penelitian ini perlu dikembangkan untuk meneliti dampak faktor budaya dan mitos yang ada di masyarakat terhadap kesehatan ibu hamil.

\section{DAFTAR PUSTAKA}

Budiman, Riyanto. (2013). Kapita Selekta Kuesioner: Pengetahuan dan Sikap dalam Penelitian
Kesehatan. Jakarta:

Salemba Medika

Devy S.R., dkk. (2011). Perawatan Kehamilan dalam Perspektif Budaya Madura di Desa Tambak dan Desa Rapalaok Kecamatan Omben Kabupaten Sampang. Jurnal Promosi Kesehatan, 1(1).

Fauziah, C. (2009). Mitos-Mitos Tentang Kehamilan. Nangroe Aceh Darussalam: Aceh Research Training

Fitria. (2009). Prinsip Dasar dan aplikasi penulisan laporan pendahuuan dan strategi pelaksanaan tindakan. Jakarta: Salemba Medika.

Harnindita. (2015). Hubungan usia, pendidikan, paritas dengan sikap ibu hamil mengenal tanda-tanda bahaya kehamilan di Puskesmas Piyungan Bantul tahun 2015. Yogyakarta: Stikes Aisyiyah.

Kementerian Kesehatan RI. (2014). Riset Kesehatan Dasar, Riskesdas 2014. Kementerian Kesehatan. Khoililurrohman. (2003). Hubungan Antara Kepercayaan Terhadap Mitos Kehamilan Dengan Perilaku Kehati-Hatian Menjelang Persalinan. Psikologi UGM Yogyakarta. 
Manuaba. 2010. Ilmu kebidanan, Penyakit Kandungan dan KB untuk Bidan. Jakarta: Arcana. Meutia. F, Swasno. (1998). Kehamilan, kelahiran, perawatan ibu dan bayi dalam aspek budaya indpnesia. Jakarta: UI. Nirwana A. B. (2011). Kapita Selekta Kehamilan. Yogyakarta: Huna Medika.

Notoatmodjo. (2003). Ilmu Kesehatan Masyarakat. $2^{\text {nd }}$ ed. Jakarta: Rineka Cipta

Priyadi. (2006). Makna Simbolis Pantangan pada Wanita Hamil di Pedesaan Banyumas. Jurnal
Pembangunan Pedesaan, 6 (3).

Syarifudin. (2010). Sosial Budaya Dasar. Jakarta: Trans Info Media

Tino. (2009). Menjawab MitosMitos Kehamilan dan Menyusui. Yogyakarta: Media Pressindo 